Article

\title{
Translationally Controlled Tumor Protein Stimulates Dopamine Release from PC12 Cells via $\mathrm{Ca}^{2+}$-Independent Phospholipase $\mathrm{A}_{2}$ Pathways
}

\author{
Jihui Seo, Jeehye Maeng and Hwa-Jung Kim * \\ College of Pharmacy, Graduate School of Pharmaceutical Sciences, Ewha Womans University, \\ Seoul 120-750, Korea; hui7505@hanmail.net (J.S.); jhmaeng@ewha.ac.kr (J.M.) \\ * Correspondence: hjkim@ewha.ac.kr; Tel.: +82-2-3277-3021; Fax: +82-2-3277-3051 \\ Academic Editor: Irmgard Tegeder \\ Received: 26 July 2016; Accepted: 10 October 2016; Published: 24 October 2016
}

\begin{abstract}
The translationally controlled tumor protein (TCTP), initially identified as a tumor- and growth-related protein, is also known as a histamine-releasing factor (HRF). TCTP is widely distributed in the neuronal systems, but its function is largely uncharacterized. Here, we report a novel function of TCTP in the neurotransmitter release from a neurosecretory, pheochromocytoma (PC12) cells. Treatment with recombinant TCTP (rTCTP) enhanced both basal and depolarization (50 mM KCl)-evoked $\left[{ }^{3} \mathrm{H}\right]$ dopamine release in concentration- and time-dependent manners. Interestingly, even though rTCTP induced the increase in intracellular calcium levels $\left(\left[\mathrm{Ca}^{2+}\right]_{\mathrm{i}}\right)$, the rTCTP-driven effect on dopamine release was mediated by a $\mathrm{Ca}^{2+}$-independent pathway, as evidenced by the fact that $\mathrm{Ca}^{2+}$-modulating agents such as $\mathrm{Ca}^{2+}$ chelators and a voltage-gated L-type $\mathrm{Ca}^{2+}$-channel blocker did not produce any changes in rTCTP-evoked dopamine release. In a study to investigate the involvement of phospholipase $\mathrm{A}_{2}\left(\mathrm{PLA}_{2}\right)$ in rTCTP-induced dopamine release, the inhibitor for $\mathrm{Ca}^{2+}$-independent $\mathrm{PLA}_{2}\left(\mathrm{iPLA}_{2}\right)$ produced a significant inhibitory effect on rTCTP-induced dopamine release, whereas this release was not significantly inhibited by $\mathrm{Ca}^{2+}$-dependent cytosolic $\mathrm{PLA}_{2}\left(\mathrm{cPLA}_{2}\right)$ and secretory $\mathrm{PLA}_{2}\left(\mathrm{sPLA}_{2}\right)$ inhibitors. We found that rTCTP-induced dopamine release from neuronal PC12 cells was modulated by a $\mathrm{Ca}^{2+}$-independent mechanism that involved PLA 2 in the process, suggesting the regulatory role of TCTP in the neuronal functions.
\end{abstract}

Keywords: translationally controlled tumor protein; histamine releasing factor; dopamine release; $\mathrm{Ca}^{2+}$-independent pathways; phospholipase $\mathrm{A}_{2} ; \mathrm{PC} 12$ neuronal cells

\section{Introduction}

The translationally controlled tumor protein (TCTP) was initially reported as a tumor-associated and growth-related protein (reviewed in [1]). Its homologs from mammalian species were reported to show extensive similarities, approximately $95 \%$ among rats and mice (P21), and humans (P23) [2,3]. In addition, TCTP was characterized as an extrinsic histamine releasing factor (HRF) because of its cytokine-like activities [4]. TCTP has been attracted an increasing number of researchers' attention because of its diverse biological functions and potentially important roles in medically relevant processes based on the fact that TCTP is ubiquitously expressed in a variety of different tissues and cell types, and its levels are highly regulated in response to various extracellular stimuli at both transcriptional and translational levels (reviewed in [1]). TCTP has been recognized as a multifunctional protein with diverse physiological and pathological roles in cell-cycle progression, proliferation, oncogenic tumorigenesis, stress response, gene regulation, cell death, and protection against cell death induced by heat shock stress, or oxidative stress. Numerous biological studies regarding its broad 
spectrum of functional importance have been presented [5], but its detailed role of TCTP especially in the nervous system remains largely elusive.

Mounting evidence has indicated the potential for the regulatory roles of TCTP in the brain functions. TCTP mRNA is expressed in many areas of the adult human brain [6], and significantly decreased TCTP expression was observed in the temporal cortex of patients with Alzheimer's disease and Down's syndrome [7] and in the schizophrenia hippocampus [8]. More recently, transcripts that encode TCTP were found to be enriched in the axonal compartment of embryonic and adult neurons [9-12], suggesting that TCTP plays an important but still unknown role in neuronal systems.

Here, motivated by the suggestive implications of TCTP in neurons and its localization in neuronal systems, we investigated the role of TCTP in the neurotransmitter release from a neurosecretory cell type, pheochromocytoma (PC12) cells. Our present study reports that TCTP enhances both basal and depolarization-evoked $\left[{ }^{3} \mathrm{H}\right]$ dopamine release and that the TCTP-triggered dopamine release from PC12 cells is mediated by $\mathrm{Ca}^{2+}$-independent, phospholipase $\mathrm{A}_{2}\left(\mathrm{PLA}_{2}\right)$-involved pathways.

\section{Results}

\subsection{Expression of Endogenous Translationally Controlled Tumor Protein (TCTP) in PC12 Cells and Rat} Brain Tissues

To examine the endogenous expression of TCTP in PC12 cells, PC12 cell homogenates were analyzed by Western blotting using a polyclonal antibody against murine TCTP. We found that the rat-originated PC12 cells were found to express TCTP with the expected size of approximately $21 \mathrm{kDa}$ (Figure 1A). The ubiquitous expression of TCTP was also confirmed in the brain regions in which dopaminergic neuronal pathways are known to be present, such as the cortex, striatum, hippocampus, thalamus, and hypothalamus (Figure 1B).

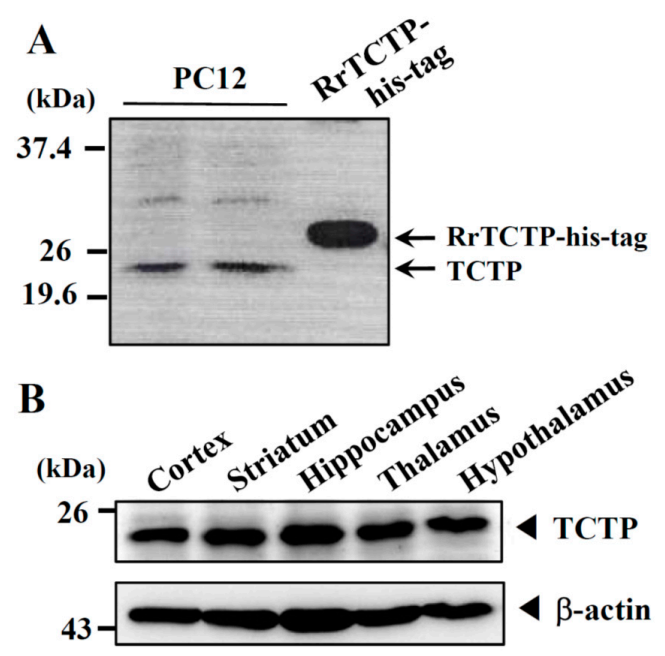

Figure 1. Endogenous translationally controlled tumor protein (TCTP) expression in PC12 cells and rat brain. Proteins extracted from PC12 cells $\left(3 \times 10^{6}\right.$ cells, about $40 \mu \mathrm{g}$; (A)), recombinant RrTCTP-his-tag $(10 \mu \mathrm{g}$; (A)); and rat brain tissues (indicated regions, $40 \mu \mathrm{g}$; (B)) were analyzed by immunoblotting using murine anti-TCTP antibody.

\subsection{Stimulatory Effect of TCTP on Basal and Depolarization-Induced Release of Dopamine from PC12 Cells}

Recombinant TCTP proteins including rat recombinant TCTP (RrTCTP) and glutathione $S$-transferase (GST)-tagged mouse recombinant TCTP (GST-MrTCTP) were expressed in Escherichia coli and purified as described in "Materials and Methods". To test whether TCTP could induce both basal and depolarization-induced dopamine release from neurosecretory PC12 cells, the cells were treated with recombinant TCTPs (rTCTPs) for $20 \mathrm{~min}$. Both RrTCTP and GST-MrTCTP enhanced the 
20-min dopamine release from PC12 cells under basal ( $5 \mathrm{mM} \mathrm{KCl}$ and $\mathrm{Ca}^{2+}$-containing) $\mathrm{KR}$ buffer conditions. RrTCTP increased dopamine release by $65 \%$ and GST-MrTCTP increased dopamine release by $50 \%$ compared with in the control $(\mathrm{CON})$ groups, whereas GST $(50 \mu \mathrm{g} / \mathrm{mL})$ alone produced no effect (Figure 2A). The rTCTP-induced stimulation of basal dopamine release was time-dependent; $\operatorname{RrTCTP}(15 \mu \mathrm{g} / \mathrm{mL})$ stimulated the dopamine release at incubation times of 20-60 min (Figure 2B). RrTCTP significantly enhanced both the spontaneous (basal) and the high $\mathrm{K}^{+}(50 \mathrm{mM} \mathrm{KCl})$-stimulated release of dopamine, at 15-40 $\mu \mathrm{g} / \mathrm{mL}$ RrTCTP in a concentration-dependent manner (Figure 2C).
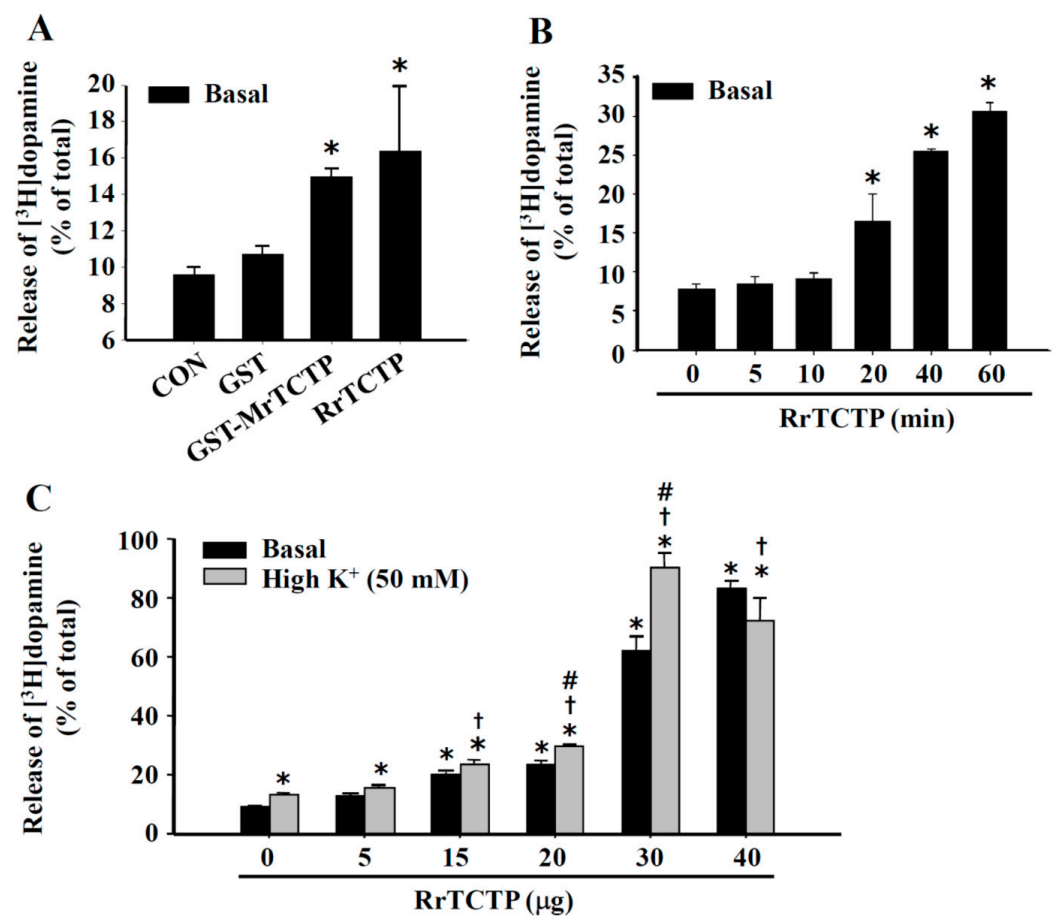

Figure 2. TCTP stimulates both basal spontaneous and depolarization (50 $\mathrm{mM} \mathrm{KCl}$ )-induced release of dopamine from PC12 cells. PC12 cells preloaded with $\left[{ }^{3} \mathrm{H}\right]$ dopamine were washed and incubated at $37{ }^{\circ} \mathrm{C}$ with rat recombinant TCTP (RrTCTP) $(15 \mu \mathrm{g} / \mathrm{mL},(\mathbf{A}, \mathbf{B}) ; 5-40 \mu \mathrm{g} / \mathrm{mL},(\mathbf{C}))$, GST-tagged mouse recombinant TCTP (GST-MrTCTP) $(50 \mu \mathrm{g} / \mathrm{mL},(\mathbf{A}))$ or GST $(50 \mu \mathrm{g} / \mathrm{mL},(\mathbf{A}))$ for $20 \mathrm{~min}(\mathbf{A}, \mathbf{C})$ or indicated time periods $(\mathbf{B})$, under basal $(5 \mathrm{mM} \mathrm{KCl})$ or high $\mathrm{K}^{+}(50 \mathrm{mM} \mathrm{KCl}) \mathrm{KR}$ buffer conditions. The amount of $\left[{ }^{3} \mathrm{H}\right]$ dopamine released into the culture supernatant was significantly increased by both RrTCTP and GST-MrTCTP, but not by GST alone (A). The rTCTP-induced stimulation of dopamine release was time- $(\mathbf{B})$ and dose-dependent $(\mathbf{C}){ }^{*} p<0.05$ relative to basal control release; $+p<0.05$ relative to high $\mathrm{K}^{+}$control release; $\# p<0.05$ relative to basal release.

\subsection{Regulation of Intracellular $\mathrm{Ca}^{2+}$ Levels by TCTP in PC12 Cells}

It is well-known that the neurotransmitter release stimulated by depolarization is $\mathrm{Ca}^{2+}$-dependent exocytotic release, but the spontaneous basal neurotransmitter release is not. To characterize the TCTP-induced stimulation of dopamine release from PC12 cells, we first investigated whether rTCTP triggered an increase in intracellular cytosolic $\mathrm{Ca}^{2+}$-concentration $\left(\left[\mathrm{Ca}^{2+}\right]_{i}\right)$. Fura-2-acetoxymethyl ester (AM), a widely used membrane permeable $\mathrm{Ca}^{2+}$ indicator, is known to be hydrolyzed by intracellular esterases, and then trapped within the cytoplasm. Fura-2-AM-loaded PC12 cells were treated with MrTCTP or $\mathrm{KCl}$ in the $\mathrm{Ca}^{2+}$-free or $\mathrm{Ca}^{2+}$-containing $\mathrm{KR}$ buffer. MrTCTP evoked a gradual and sustained increase in $\left[\mathrm{Ca}^{2+}\right]_{\mathrm{i}}$ in the $\mathrm{Ca}^{2+}$-containing buffer condition but not in the absence of extracellular $\mathrm{Ca}^{2+}$ (Figure 3A), similar to the effects on $\left[\mathrm{Ca}^{2+}\right]_{i}$ with $50 \mathrm{mM} \mathrm{KCl}$; these reactions mimicked those in the highly depolarized condition except that $\mathrm{KCl}$ produced a rapid rise in $\left[\mathrm{Ca}^{2+}\right]_{\mathrm{i}}$ (Figure 3B). Removal of cytosolic $\mathrm{Ca}^{2+}$ by BAPTA-AM, a cell-permeant $\mathrm{Ca}^{2+}$ chelator, reduced the basal level of $\left[\mathrm{Ca}^{2+}\right]_{\mathrm{i}}$ 
and abolished the rTCTP-induced $\left[\mathrm{Ca}^{2+}\right]_{\mathrm{i}}$ rise in the $\mathrm{Ca}^{2+}$-containing buffer condition (Figure 3C). It has been shown that, in PC12 cells, membrane depolarization by $\mathrm{KCl}$ results in an influx of $\mathrm{Ca}^{2+}$ through depolarization-induced activation of voltage-sensitive $\mathrm{Ca}^{2+}$ channels, thereby triggering exocytosis $[13,14]$. The $\mathrm{Ca}^{2+}$ current evoked by rTCTP was not affected by treatment with an L-type $\mathrm{Ca}^{2+}$ channel inhibitor, nifedipine $(2 \mu \mathrm{M})$, as shown in Figure 3D; meanwhile $\mathrm{Ca}^{2+}$ current evoked by $\mathrm{KCl}$ was inhibited (data not shown). This finding suggests that unlike $\mathrm{KCl}$, voltage-gated L-type $\mathrm{Ca}^{2+}$ channels are not involved in MrTCTP-induced $\mathrm{Ca}^{2+}$ current.
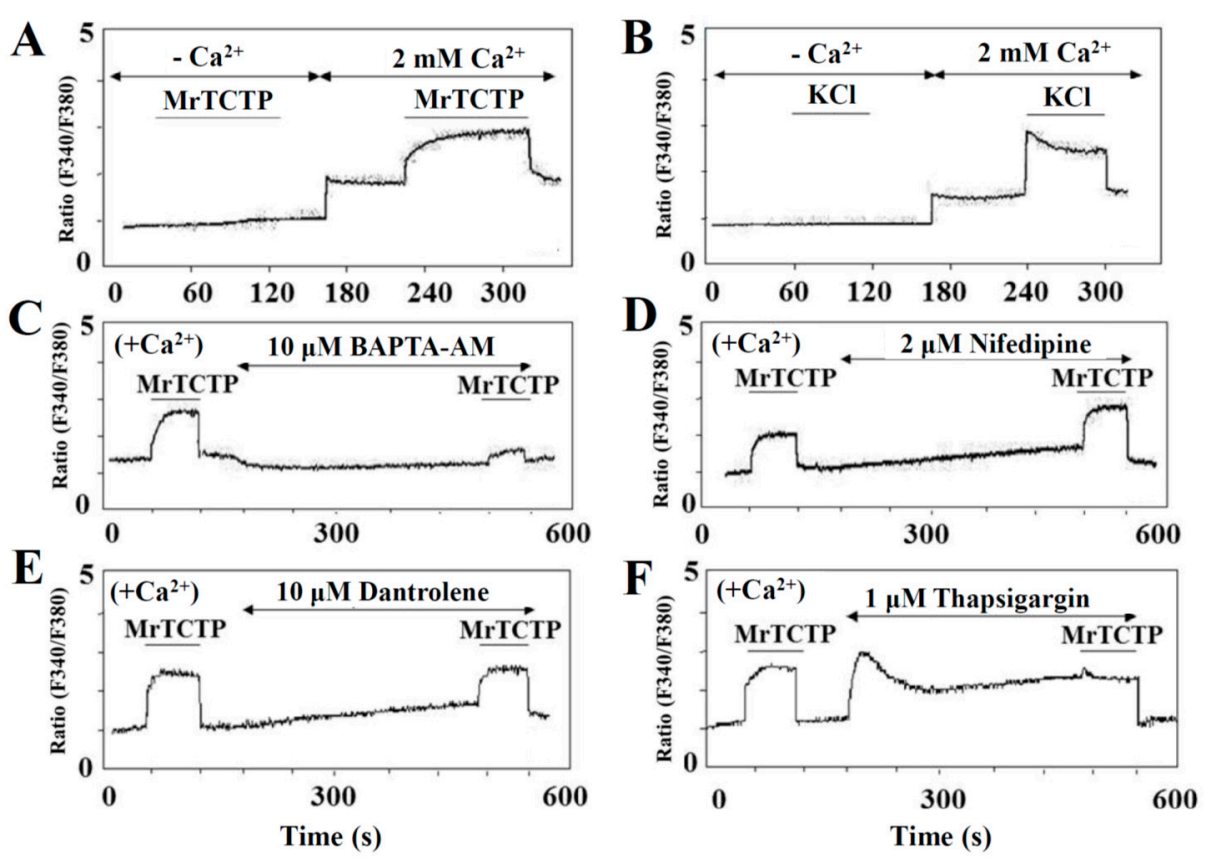

Figure 3. TCTP increases intracellular $\mathrm{Ca}^{2+}$ concentration. PC12 cells were loaded with $5 \mu \mathrm{M}$ Fura-2-AM (acetoxymethyl) for $30 \mathrm{~min}$ and then washed multiple times. The fluorescence experiments were carried out at room temperature in the $\mathrm{Ca}^{2+}\left(2 \mathrm{mM} \mathrm{CaCl}_{2}\right)$-containing buffer $\left(+\mathrm{Ca}^{2+}\right)$, or the $\mathrm{Ca}^{2+}$-free buffer supplemented with $0.5 \mathrm{mM}$ ethylene glycol-bis( $\beta$-aminoethyl ether)- $N, N, N^{\prime}, N^{\prime}$-tetraacetic acid (EGTA) $\left(-\mathrm{Ca}^{2+}\right)$. Cells were treated for the indicated times with $50 \mu \mathrm{g} / \mathrm{mL}$ MrTCTP (A) or $50 \mathrm{mM} \mathrm{KCl} \mathrm{(B).} \mathrm{In} \mathrm{some} \mathrm{experiments,} \mathrm{cells} \mathrm{were} \mathrm{treated} \mathrm{with} \mathrm{MrTCTP} \mathrm{after}$ pretreatment for 5 min with $10 \mu \mathrm{M}$ BAPTA-AM (C); $2 \mu \mathrm{M}$ niffedipine (D); and $10 \mu \mathrm{M}$ dantrolene (E); or $1 \mu \mathrm{M}$ thapsigargin $(\mathbf{F})$.

Next, it was further investigated whether the rTCTP-induced $\left[\mathrm{Ca}^{2+}\right]_{\mathrm{i}}$ increase was due to the mobilization of $\mathrm{Ca}^{2+}$ from intracellular stores by utilizing dantrolene, which blocks $\mathrm{Ca}^{2+}$ release from the endoplasmic reticulum (ER). The rTCTP-evoked cytosolic $\mathrm{Ca}^{2+}$ current was also not affected by dantrolene $(10 \mu \mathrm{M})$, as shown in Figure 3E. Our data indicate that the rTCTP-induced increase in $\left[\mathrm{Ca}^{2+}\right]_{\mathrm{i}}$ was due to a $\mathrm{Ca}^{2+}$ influx from an extracellular source rather than via voltage-gated L-type $\mathrm{Ca}^{2+}$ channels, and that rTCTP does not mobilize $\mathrm{Ca}^{2+}$ from intracellular stores. Thapsigargin, an inhibitor of $\mathrm{Ca}^{2+}$-ATPase in the membranes of ER $\mathrm{Ca}^{2+}$ stores, is generally used to inhibit refilling of $\mathrm{Ca}^{2+}$ stores and subsequently depleting $\mathrm{Ca}^{2+}$ from $\mathrm{Ca}^{2+}$ stores in various cells $[15,16]$, including PC12 cells. When PC12 cells were exposed to $1 \mu \mathrm{M}$ thapsigargin in a $\mathrm{Ca}^{2+}$-containing buffer, it caused a sustained increase in $\left[\mathrm{Ca}^{2+}\right]_{i}$, confirming that intracellular $\mathrm{Ca}^{2+}$ stores are releasable under our experimental conditions. When $50 \mu \mathrm{g}$ MrTCTP were added in the medium that contained both $\mathrm{Ca}^{2+}$ and thapsigargin, further rise in $\left[\mathrm{Ca}^{2+}\right]_{i}$ was not produced by rTCTP (Figure 3F). 


\section{4. $\mathrm{Ca}^{2+}$-Independent Release of Dopamine by TCTP from PC12 Cells}

To investigate whether the rTCTP-evoked dopamine release was $\mathrm{Ca}^{2+}$-dependent and the $\left[\mathrm{Ca}^{2+}\right]_{\mathrm{i}}$ changes induced by rTCTP played a role in the rTCTP-induced enhancement of dopamine release, effects of $\mathrm{Ca}^{2+}$ chelators that removed extracellular and intracellular $\mathrm{Ca}^{2+}$ sources, and $\mathrm{Ca}^{2+}$ inhibitors (nifedipine or dantrolene) on dopamine release from PC12 cells were examined. Unexpectedly, rTCTP stimulated dopamine release even in the absence of extracellular $\mathrm{Ca}^{2+}$ by a similar extent to that in the presence of extracellular $\mathrm{Ca}^{2+}$. In contrast, both bradykinin $(1 \mu \mathrm{M})$ and $\mathrm{KCl}(50 \mathrm{mM})$ stimulated dopamine release only in the $\mathrm{Ca}^{2+}$-containing media, and did not induce dopamine release in the absence of extracellular $\mathrm{Ca}^{2+}\left(\mathrm{Ca}^{2+}\right.$-free media + EDTA (ethylenediaminetetraacetic acid)) (Figure 4A). The $\mathrm{Ca}^{2+}$-independence of the rTCTP-evoked dopamine release was further confirmed by the observations that BAPTA-AM $(10$ and $50 \mu \mathrm{M})$, nifedipine $(2 \mu \mathrm{M})$ and dantrolene $(10 \mu \mathrm{M})$ did not significantly inhibit rTCTP-evoked dopamine release either in the presence or in the absence of extracellular $\mathrm{Ca}^{2+}$ (Figure 4B-D), although some of the agents blocked rTCTP-evoked intracellular $\mathrm{Ca}^{2+}$ peak in a $\mathrm{Ca}^{2+}$-containing buffer (Figure 3). These data indicate that even though rTCTP induced an influx of $\mathrm{Ca}^{2+}$, the rTCTP-induced enhancement of dopamine release was largely regulated by $\mathrm{Ca}^{2+}$-independent processes, and that $\left[\mathrm{Ca}^{2+}\right]_{\mathrm{i}}$ increased by rTCTP played only a minor role if any in the rTCTP-evoked dopamine release from PC12 cells.
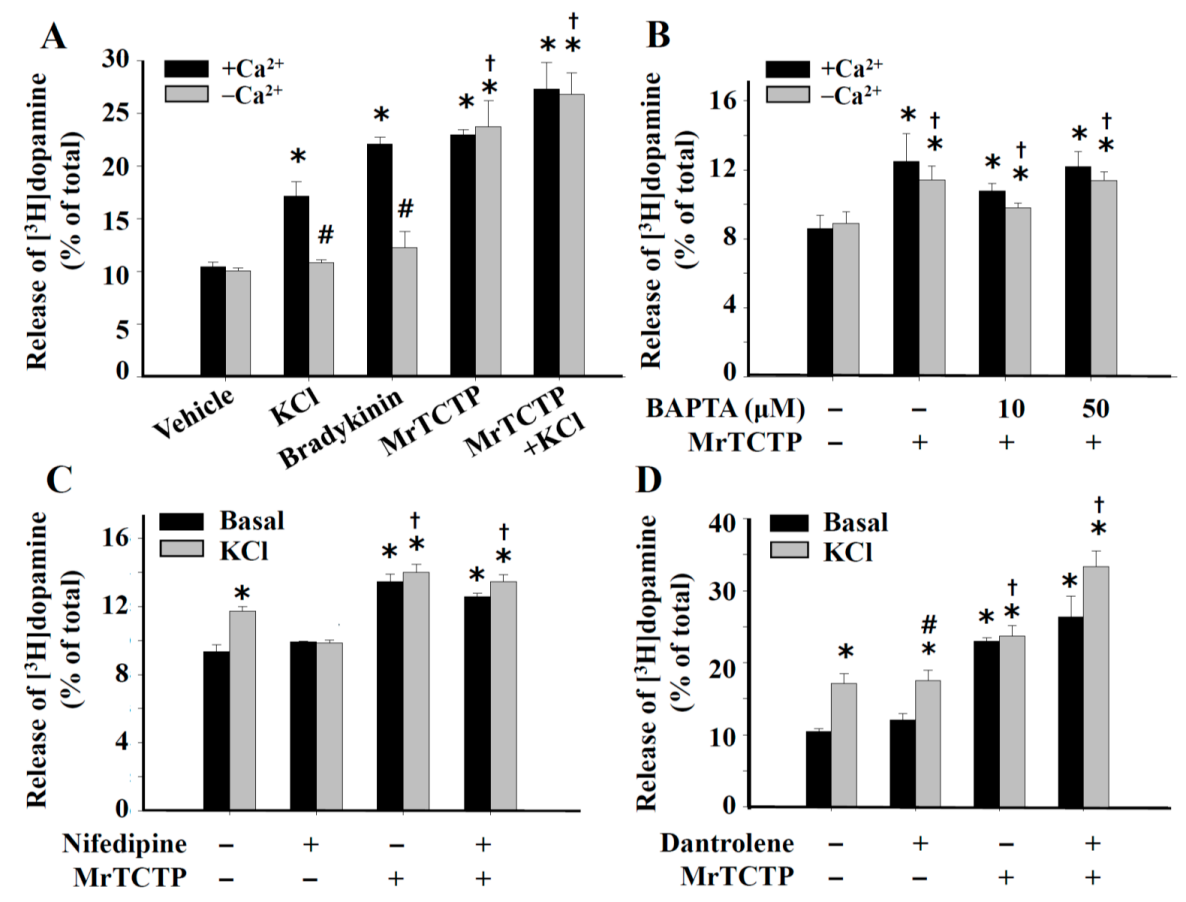

Figure 4. TCTP induced dopamine release from $\mathrm{PC} 12$ cells via $\mathrm{Ca}^{2+}$-independent pathways. $\left[{ }^{3} \mathrm{H}\right]$ Dopamine-preloaded PC12 cells were washed and treated in $\mathrm{Ca}^{2+}$-containing buffer $\left(+\mathrm{Ca}^{2+}\right)$ or $\mathrm{Ca}^{2+}$-free buffer $\left(-\mathrm{Ca}^{2+}\right)$ with $50 \mathrm{mM} \mathrm{KCl}, 1 \mu \mathrm{M}$ bradykinin, and $50 \mu \mathrm{g} / \mathrm{mL} \operatorname{MrTCTP}(\mathbf{A})$; $\left[{ }^{3} \mathrm{H}\right]$ Dopamine-preloaded PC12 cells were washed, pretreated for $20 \mathrm{~min}$ at $37^{\circ} \mathrm{C}$ with 10 or $50 \mu \mathrm{M}$ BAPTA-AM (B); $2 \mu \mathrm{M}$ nifedipine (C); or $10 \mu \mathrm{M}$ dantrolene (D); and then treated for 20 min with $50 \mu \mathrm{g} / \mathrm{mL}$ MrTCTP with the continued presence of above agent where indicated, in the basal and the high $\mathrm{K}^{+}(50 \mathrm{mM} \mathrm{KCl})$ buffers. $\left[{ }^{3} \mathrm{H}\right]$ Dopamine release into media is expressed as relative to total $\left[{ }^{3} \mathrm{H}\right]$ dopamine loaded. Data are presented as Mean \pm S.E.M. (standard error of mean) $* p<0.05$ relative to control basal release; $+p<0.05$ relative to control high $\mathrm{K}^{+}$release; $\# p<0.05$ relative to respective basal release. 
2.5. Involvement of $\mathrm{Ca}^{2+}$-Independent Phospholipase $A_{2}\left(P L A_{2}\right)$ in TCTP-Induced Dopamine Release from PC12 Cells

It has been shown that a polypeptide composed of 33 amino acids-pardaxin-stimulates exocytosis in the neuronal systems by both $\mathrm{Ca}^{2+}$-dependent and $\mathrm{Ca}^{2+}$-independent mechanisms $[17,18]$. A direct relationship was proposed between pardaxin-induced dopamine release and the arachidonic acid cascades. Arachidonic acid, a major fatty acid produced by $\mathrm{Ca}^{2+}$-dependent or $\mathrm{Ca}^{2+}$-independent activation of $\mathrm{PLA}_{2}$, serves as a precursor of eicosanoids that mediate diverse physiological and pathophysiological processes in brain and other tissues $[19,20]$.

To investigate whether the $\mathrm{PLA}_{2}$ signaling is also associated as a mechanism involved in the TCTP-induced dopamine release in PC12 cells, several inhibitors of PLA $\mathrm{A}_{2}$ isoforms were used. PC12 cells were pre-incubated for 20 min with $25 \mu \mathrm{M}$ arachidonyl trifluoromethyl ketone (AACOCF 3 ) (a cytosolic PLA 2 (cPLA $)_{2}$ inhibitor), $10 \mu \mathrm{M}$ 1-palmitylthio-2-palmitoylamino-1,2-dideoxy-sn-glycero3-phosphorylcholine (TEA-PC) (a secretory $\mathrm{PLA}_{2}$ (sPLA $_{2}$ ) inhibitor), or $25 \mu \mathrm{M}$ bromoenol lactone (BEL) (a Ca ${ }^{2+}$-independent $\mathrm{PLA}_{2}\left(\mathrm{iPLA}_{2}\right)$ inhibitor), and thereafter treated with $50 \mu \mathrm{g} / \mathrm{mL}$ MrTCTP for an additional $20 \mathrm{~min}$ in a $\mathrm{Ca}^{2+}$-containing medium. As shown in Figure 5A, TEA-PC and AACOCF3 produced no significant changes, but BEL significantly inhibited the rTCTP-induced dopamine release (Figure 5A), indicating the possibility of iPLA 2 involvement in rTCTP-evoked dopamine release.

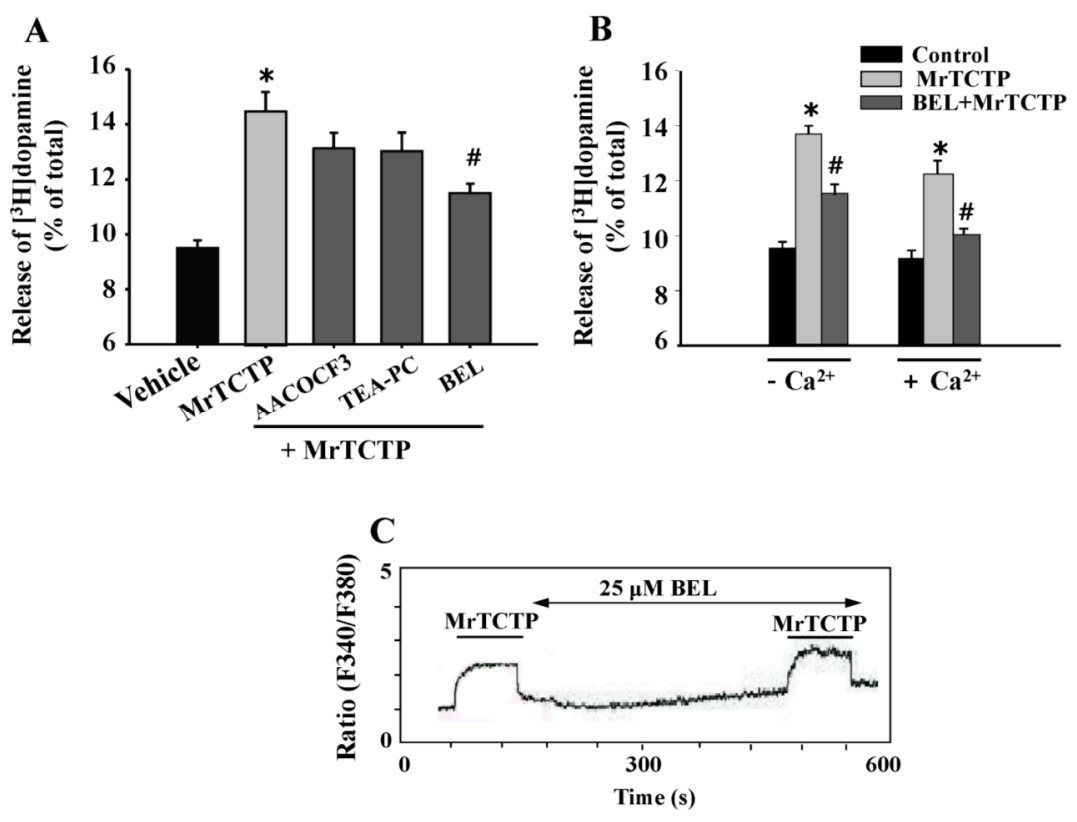

Figure 5. The effects of phospholipase $\mathrm{A}_{2}\left(\mathrm{PLA}_{2}\right)$ inhibitors on TCTP-induced dopamine release from PC12 cells. (A,B) PC12 cells were pre-incubated for $20 \mathrm{~min}$ at $37^{\circ} \mathrm{C}$ with $25 \mu \mathrm{M} \mathrm{AACOCF} 3$, $10 \mu \mathrm{M}$ TEA-PC, or $25 \mu \mathrm{M}$ BEL, and then treated with $50 \mu \mathrm{g} / \mathrm{mL}$ MrTCTP for an additional $20 \mathrm{~min}$ in $\mathrm{Ca}^{2+}$-containing $\left(+\mathrm{Ca}^{2+}\right)$, or $\mathrm{Ca}^{2+}$-free $\left(-\mathrm{Ca}^{2+}\right)$ buffer. The amount of $\left[{ }^{3} \mathrm{H}\right]$ dopamine released into the culture supernatant was measured. ${ }^{*} p<0.05$ relative to control release; $\# p<0.05$ relative to MrTCTP-treated release; $(C)$ the fluorescence experiments were carried out at room temperature in the $\mathrm{Ca}^{2+}\left(2 \mathrm{mM} \mathrm{CaCl}_{2}\right)$-containing buffer. PC12 cells were loaded with $5 \mu \mathrm{M}$ Fura-2-AM for 30 min and then washed multiple times. The cells were pretreated with $25 \mu \mathrm{M}$ BEL for $5 \mathrm{~min}$, and then exposed to $50 \mu \mathrm{g} / \mathrm{mL}$ MrTCTP.

Among the three major $\mathrm{PLA}_{2}$ families, only iPLA ${ }_{2}$ can be activated under $\mathrm{Ca}^{2+}$-free conditions [21,22]. It has been reported that even though iPLA $\mathrm{PL}_{2}$ does not require $\mathrm{Ca}^{2+}$ for activity, it may be modulated by $\mathrm{Ca}^{2+}$ or $\mathrm{Ca}^{2+}$-dependent factors in cells [23], and it can regulate store-operated $\mathrm{Ca}^{2+}$ entry in rat cerebellar astrocytes [24]. Treatment with BEL $(25 \mu \mathrm{M})$ significantly inhibited the release of dopamine induced by MrTCTP not only in $\mathrm{Ca}^{2+}$-containing buffer but also in $\mathrm{Ca}^{2+}$-free 
buffer (Figure 5B). However, BEL $(25 \mu \mathrm{M})$ did not affect MrTCTP-evoked intracellular $\mathrm{Ca}^{2+}$ peak in a Ca ${ }^{2+}$-containing buffer (Figure 5C). These findings further confirm that $\mathrm{PLA}_{2}$ is involved in the rTCTP-induced dopamine release from PC12 cells in a $\mathrm{Ca}^{2+}$-independent fashion.

\section{Discussion}

In the present study, we investigated the novel function of TCTP in dopamine release, focusing on its $\mathrm{Ca}^{2+}$-independent regulation of neurotransmitter release in rat pheochromocytoma PC12 cells in which endogenous TCTP protein expression is detected (Figure 1). The PC12 cells have been widely used and well characterized in in vitro models for studying neuronal function and signaling processes [25], since it was reported that dopamine, norepinephrine, ATP, and various proteins were stored in secretory vesicles, and chromaffin granules of undifferentiated PC12 cells [14].

TCTP is known to be involved in a great variety of physiological processes such as cellular proliferation and development, microtubule stabilization, protein synthesis, cell cycle progression, stress responses, and cytokine release through its responses to extracellular stimuli [1]. However, both deregulated expression and uncontrolled action of TCTP are implicated in many pathological conditions, such as allergies and inflammation, tumor progression, and neurodegenerative disorders [1]. Diverse intracellular functional mechanisms of TCTP/HRF have been presented in numerous studies, although detailed mechanisms are still elusive. It has been suggested that the receptor and signaling mechanisms of TCTP/HRF might not yet have been fully identified.

Many studies have indicated the potential association of TCTP in the physiology and pathology of the nervous system. TCTP transcript has been shown to be expressed abundantly in many areas of embryonic and adult neurons [6]. TCTP's implications in pathophysiological conditions in the human brain was first reported by Kim et al. [7], specifically that significantly decreased TCTP expression was observed in the temporal cortices of patients with Alzheimer's disease and Down's syndrome. Later, Chung et al. [8] also demonstrated the reduced level of TCTP levels in the schizophrenia hippocampus. This evidence suggests that TCTP is involved in the physiological regulation of cognitive functions in the hippocampus and that decreased TCTP may result in the development of neurodegenerative or dementia-triggering disorders. An increasing number of studies further suggest the importance of TCTP in the brain and neuronal cell systems by showing that TCTP mRNAs or proteins are enriched in specific neuronal compartments, especially in the axonal region of neurons [9-12]. Based on the TCTP expression in PC12 cells and in brain regions in which dopaminergic neuronal pathways are present (Figure 1), here, we hypothesized here that TCTP might also regulate the neurotransmitter release, suggesting its novel functional role in neuronal systems.

In neuronal cells including PC12 cells, membrane depolarization by $\mathrm{KCl}$ resulted in $\mathrm{Ca}^{2+}$ influx through depolarization-induced activation of voltage-gated $\mathrm{Ca}^{2+}$ channels, which thereby triggered neurotransmitter release $[13,26]$. Extracellular $\mathrm{Ca}^{2+}$ influx was also suggested to play an essential role in bradykinin receptor-mediated dopamine release from PC12 cells $[27,28]$. We found that dopamine release from PC12 cells was stimulated by exogenous treatment with rTCTPs, which not only triggered basal dopamine release in concentration- and time-dependent manners but also additively increased the high $\mathrm{K}^{+}$-stimulated (depolarization-induced) dopamine release in PC12 cells (Figure 2). These results indicate that the rTCTP-evoked dopamine release might different from that of high $\mathrm{K}^{+}$-stimulated exocytotic dopamine release. In addition, rTCTP evoked an evident cytosolic $\mathrm{Ca}^{2+}$-response but it was not related to the rTCTP-induced dopamine release in PC12 cells (Figures 3 and 4). The stimulation of intracellular $\mathrm{Ca}^{2+}$-response and dopamine release by high $\mathrm{K}^{+}$ $(50 \mathrm{mM} \mathrm{KCl})$ or bradykinin was observed to be extracellular $\mathrm{Ca}^{2+}$-dependent (Figures 3B and $4 \mathrm{~A}$ ). In contrast, RrTCTP stimulated dopamine release even in the absence of extracellular $\mathrm{Ca}^{2+}$ (Figure 4A) or blocking L-type $\mathrm{Ca}^{2+}$ channels by nifedipine (Figure 4C), although the RrTCTP-evoked increase in $\left[\mathrm{Ca}^{2+}\right]_{i}$ was abolished in $\mathrm{Ca}^{2+}$-free media (Figure 3A) and media that contained BAPTA-AM (Figure 3C).

The role of $\mathrm{Ca}^{2+}$ in neurotransmitter release has been widely investigated, but extracellular $\mathrm{Ca}^{2+}$-independent release of various neurotransmitters including, acetylcholine [29], $\gamma$-aminobutyric 
acid [30], glutamate [31], and dopamine [32] has also been reported in depolarizedf brain slices or synaptosomes. One explanation for the extracellular $\mathrm{Ca}^{2+}$-independent neurotransmitter release is that depolarization induces a conformational change in certain cell membrane proteins to be sensitive to intracellular $\mathrm{Ca}^{2+}$, leading to stimulate exocytosis [33]. According to this hypothesis, the mobilization of $\mathrm{Ca}^{2+}$ from intracellular $\mathrm{Ca}^{2+}$ stores could be a prerequisite for neurotransmitter release. Therefore, we investigated whether modifying intracellular $\mathrm{Ca}^{2+}$ would affect rTCTP-stimulated dopamine release. Of interest, rTCTP-stimulated dopamine release does not need to be accompanied by changes in cytosolic $\mathrm{Ca}^{2+}$ because MrTCTP induced dopamine release even when the intracellular $\mathrm{Ca}^{2+}$ was buffered with a cell-permeant $\mathrm{Ca}^{2+}$ chelator in the presence of extracellular $\mathrm{Ca}^{2+}$ (Figures $3 \mathrm{C}$ and $4 \mathrm{~B}$ ), as well as in the absences of extracellular $\mathrm{Ca}^{2+}$. It is also reasonable to assume that $\mathrm{Ca}^{2+}$ mobilization from intracellular stores is not the major mechanism by which rTCTP stimulates dopamine release, as evidenced by our observation that treatment of $\mathrm{PC} 12$ cells with dantrolene-which blocks $\mathrm{Ca}^{2+}$ release from the ER-did not affect MrTCTP-induced dopamine release in the presence of extracellular $\mathrm{Ca}^{2+}$ (Figure 4D).

The ability of rTCTP to stimulate neurotransmitter release in the absence of extracellular $\mathrm{Ca}^{2+}$ and without $\mathrm{Ca}^{2+}$ mobilization from intracellular stores provide a unique view for the mechanisms of $\mathrm{Ca}^{2+}$-independent neurotransmitter release. Arachidonic acid and its metabolites are likely candidates in $\mathrm{Ca}^{2+}$-independent neurotransmitter release $[17,34]$. $\mathrm{PLA}_{2} \mathrm{~S}$ are involved in a variety of cellular functions, including signal transduction and exocytosis [19,35]. In a number of studies with PC12 cells, $\mathrm{PLA}_{2} \mathrm{~S}$ are suggested to be involved in both $\mathrm{Ca}^{2+}$-dependent exocytosis [36-39] and in $\mathrm{Ca}^{2+}$-independent [34] exocytosis. All major $\mathrm{PLA}_{2}$ groups $\left(\mathrm{cPLA}_{2} \mathrm{~s}, \mathrm{sPLA}_{2} \mathrm{~s}\right.$, and $\mathrm{Ca}^{2+}$-independent ${ }_{i P L A} \mathrm{~s}$ ) are present in the central nervous system [40,41], and iPLA $A_{2}$ was also suggested to be the major $\mathrm{PLA}_{2}$ in the cytosolic fraction of developing and adult rat brains [42]. We showed that rTCTP-triggered dopamine release was significantly blocked by an $\mathrm{iPLA}_{2}$ inhibitor, $\mathrm{BEL}$, but not by inhibitor of either $\mathrm{cPLA}_{2}\left(\mathrm{AACOCF}_{3}\right)$ or $\mathrm{SPLA}_{2}$ (TEA-PC) inhibitors (Figure 5A). The iPLA $\mathrm{P}_{2}$-dependent dopamine release by rTCTP was not accompanied with the rTCTP-evoked cytosolic $\mathrm{Ca}^{2+}$ response that was not affected by iPLA 2 inhibition (Figure 5 C).

A number of studies have proposed iPLA 2 as an essential molecular player in store-operated $\mathrm{Ca}^{2+}$ entry in many excitable and non-excitable cells [24,43], but this mechanisms is not likely to be involved in cytosolic $\mathrm{Ca}^{2+}$ response induced by rTCTP. When extracellular $\mathrm{Ca}^{2+}$ was removed to rule out the contribution of $\mathrm{Ca}^{2+}$-dependent enzymes, BEL still had its inhibitory effect on dopamine release enhanced by rTCTP. Vonakis et al. [44] reported that rTCTP/HRF increased the arachidonic acid metabolite leukotriene $\mathrm{C}_{4}$ from basophils, which is related to the intracellular $\mathrm{Ca}^{2+}$ response induced by rTCTP/HRF. In contrast, HRF/TCTP could induce secretion of both histamine and interleukin-4 in human basophils [45], in which histamine release did not need to be accompanied by changes in cytosolic $\mathrm{Ca}^{2+}$ [46]. From our data, it can be postulated that TCTP may be involved in the increases of arachidonic acid and its metabolites through $\mathrm{Ca}^{2+}$-independent $\mathrm{PLA}_{2}$ pathways resulting in dopamine release in neuronal cells. Although BEL is known to be a selective and potent inhibitor of iPLA 2 $\left(\mathrm{iPLA}_{2} \beta\right)$, it is also reported to inhibit non-PLA $\mathrm{P}_{2}$ enzymes in signal transduction (e.g., phosphatidate phosphohydrolase), which may be responsible for the arachidonic acid release [47]. The involvement of signaling pathways other than iPLA 2 cannot be ruled out in the neurotransmitter release mechanisms of TCTP through $\mathrm{Ca}^{2+}$-independent signaling. Our future studies aim to decipher the specified mechanisms of TCTP in dopamine release and to dissect the signaling pathways how activated PLA 2 is linked with the process of neurotransmitter release.

\section{Materials and Methods}

\subsection{Materials and Reagents}

[ $\left.{ }^{3} \mathrm{H}\right]$ Dopamine $(125 \mu \mathrm{Ci} / \mathrm{mmol})$ was purchased from Amersham Bioscience Corp. (Piscataway, NJ, USA) and the Scintillation cocktails (ScintiSafe ${ }^{\mathrm{TM}}$ Econo2) were from Thermo Fisher Scientific 
(Waltham, NJ, USA). Bromoenol lactone (BEL), arachidonyl trifluoromethyl ketone ( $\left.\mathrm{AACOCF}_{3}\right)$, and 1-palmitylthio-2-palmitoylamino-1,2-dideoxy-sn-glycero-3-phosphorylcholine (TEA-PC) were from Biomol Research Laboratories (Plymouth Meeting, PA, USA). Nickel-nitrilotriacetic acid (Ni-NTA) resins were from Qiagen (Stanford, CA, USA). Fura-2 acetoxymetyl ester (Fura-2-AM) was purchased from Molecular Probes (Eugene, OR, USA). Pargyline, desipramine, bradykinin, nifedipine, dantrolene, ethylene glycol-bis ( $\beta$-aminoethyl ether)- $N, N, N^{\prime}, N^{\prime}$-tetraacetic acid (EGTA), 1,2-bis(2-aminophenoxy)ethane- $N, N, N^{\prime}, N^{\prime}$-tetraacetic acid acetoxymethyl ester (BAPTA-AM), isopropylthiogalactoside (IPTG), and other chemicals and reagents were purchased from Sigma Aldrich (St. Louis, MO, USA) or BD Difco (Frankline Laks, NJ, USA). Stock solutions for Fura-2-AM, BAPTA-AM, BEL, AACOCF 3 , TEA-PC, dantrolene, and bradykinin were prepared by dissolving the compounds in dimethyl sulfoxide (DMSO), and then further diluted in serum-free media; final DMSO concentrations did not exceed $0.2 \%(v / v)$. RPMI 1640, penicillin/streptomycin, horse serum, and fetal bovine serum (FBS) were obtained from GIBCO (Grand Island, NY, USA).

\subsection{Expression and Purification of TCTP}

Rat homolog of TCTP (RTCTP) cDNA was cloned into a T7 expression vector, pRSET-A and expressed as a hexa-histidine-tagged protein. Mouse TCTP (MTCTP) cDNA was cloned into a pGEX-4T3 plasmid vector and expressed as a fusion protein with the glutathione $S$-transferase (GST). GST occurs naturally as a $26 \mathrm{kDa}$ protein that can be expressed in E. coli with full enzymatic activity. The recombinant plasmids were transformed into E. coli BL21(DE3)pLysS and were expressed by the protein induction under treatment with 0.4 or $1 \mathrm{mM}$ IPTG. Expressed proteins including MrTCTP and RrTCTP were purified by metal-affinity chromatography using nickel-nitrilotriacetic acid (Ni-NTA) metal-affinity chromatography and glutathione-agarose affinity chromatography, respectively, according to the manufacturer's instructions. The contents of the purified proteins were determined with the Pierce-BCA protein assay kit (Rockford, IL, USA) using bovine serum albumin (BSA), and were analyzed by sodium dodecyl sulfate (SDS)-polyacrylamide gel electrophoresis (PAGE). Purified proteins were stored at $-70{ }^{\circ} \mathrm{C}$ until use.

\subsection{Neuronal Cell Culture}

Rat PC12 cells (ATCC number: CRL-1721) were grown in RPMI 1640 media supplemented with $10 \%$ horse serum, $5 \%$ fetal bovine serum (FBS), 100 units $/ \mathrm{mL}$ penicillin, and $100 \mu \mathrm{g} / \mathrm{mL}$ streptomycin. The cultures were maintained in an incubator at $37{ }^{\circ} \mathrm{C}$ in humidified conditions under $5 \% \mathrm{CO}_{2}$. The medium was changed twice weekly, and the cultures were split at 1:5 ratios every five days. Passages 5 through 15 were used. In all experiments, the cells were plated on two-well dishes coated with poly-L-lysine $(0.01 \mathrm{mg} / \mathrm{mL})$.

\subsection{SDS-Polyacrylamide Gel Electrophoresis (PAGE) and Western Blotting}

PC 12 cells were lysed with modified radioimmunoprecipitation assay (RIPA) lysis buffer (50 mM Tris-HCl, $150 \mathrm{mM} \mathrm{NaCl}, 1 \% \mathrm{NP}-40,0.25 \%$ deoxycholate, 1 mM EGTA, pH 8.0), supplemented with $1 \%$ protease inhibitor cocktail was added to the lysis buffer immediately prior to use). The whole-cell lysate was prepared by $12,200 \times g$ for $20 \mathrm{~min}$ at $4{ }^{\circ} \mathrm{C}$, and the supernatant was collected. Rat brain tissues were collected from two adult rats (6-8 weeks old) in a cold lysis buffer (1\% Triton X-100, $1 \mathrm{mM}$ ethylenediaminetetraacetic acid (EDTA) in phosphate buffered saline (PBS) , protease inhibitor cocktail), homogenized and put on ice for $20 \mathrm{~min}$, and then centrifuged at 10,000 $\times \mathrm{g}$ for $10 \mathrm{~min}$ at $4{ }^{\circ} \mathrm{C}$. Protein content was determined in the homogenized striatal tissue samples by using a BCATM protein assay kit (Thermo Fisher Scientific (Waltham, NJ, USA)), and was assessed for Western blotting analyses. Equal aliquots of the samples were denatured at $100{ }^{\circ} \mathrm{C}$ and then electrophoresed through $12 \%$ SDS-PAGE. Proteins were transferred to polyvinylidene difluoride (PVDF) membranes in transfer buffer ( $25 \mathrm{mM}$ Tris-Cl, $\mathrm{pH} 8.3,192 \mathrm{mM}$ glycine, 20\% methanol) for $2 \mathrm{~h}$. Nonspecific bindings were blocked in Tris-buffered saline ( $\mathrm{pH} 7.4$ ) containing $0.1 \%$ tween 20 (TBS-T) and 5\% BSA for $2 \mathrm{~h}$ at 
room temperature. Primary anti-TCTP antibodies (kindly provided by Prof. Kyounglim Lee at Ewha Womans University) were diluted (1:4000) in TBS-T (137 mM NaCl, $20 \mathrm{mM}$ Tris-Cl, $0.1 \%$ Tween 20, $\mathrm{pH}$ 7.6) and incubated with the membrane for $2 \mathrm{~h}$. Excess primary antibody was removed by washing the membranes four times in TTBS. The blots were then incubated with secondary antibody diluted in TBS-T (1:3000). Immunoreactive proteins were detected by enhanced chemiluminescence (ECL) system using a luminescent image analyzer LAS-1000 and IMAGE GAUSE software (Fuji Photo Film, Tokyo, Japan).

\section{5. $\left[{ }^{3}\right.$ H]Dopamine Release}

PC12 cells were grown in 24-well dishes in serum-containing medium for $24 \mathrm{~h}$ at $37{ }^{\circ} \mathrm{C}$. The medium was removed and cells were loaded with fresh serum-free medium containing $\left[{ }^{3} \mathrm{H}\right]$ dopamine $(0.5 \mu \mathrm{Ci} / \mathrm{mL})$ for $3 \mathrm{~h}$ at $37^{\circ} \mathrm{C}$. The medium was removed and the cells were washed three times with PBS containing $1 \mathrm{mM}$ ascorbic acid. To measure both basal and depolarized dopamine release, cells treated with various indicated reagents including rTCTPs were incubated at $37^{\circ} \mathrm{C}$ for $20 \mathrm{~min}$ in $1 \mathrm{~mL}$ Krebs-Ringer-HEPES (4-(2-hydroxyethyl)-1-piperazineethanesulfonic acid) buffer $\left(125 \mathrm{mM} \mathrm{NaCl}, 5 \mathrm{mM} \mathrm{KCl}, 2 \mathrm{mM} \mathrm{CaCl}_{2}, 10 \mathrm{mM}\right.$ HEPES, $1.2 \mathrm{mM} \mathrm{MgSO}_{4}, 1.2 \mathrm{mM} \mathrm{KH}_{2} \mathrm{PO}_{4}, 6 \mathrm{mM}$ glucose, $5 \mathrm{mM} \mathrm{NaHCO} 3$, supplemented with pargyline or desipramine) and the buffer containing $50 \mathrm{mM} \mathrm{KCl}$, respectively. EGTA $(0.5 \mathrm{mM})$ was added to the $\mathrm{Ca}^{2+}$-free (without $\mathrm{CaCl}_{2}$ ) media. Samples were centrifuged for $10 \mathrm{~min}$ at $1000 \times \mathrm{g}$ at $4{ }^{\circ} \mathrm{C}$ to remove floating cells, and the supernatant was harvested and $0.2 \mathrm{~mL}$ was measured for released radioactivity. For total radioactivity, the cells were washed with PBS and solubilized in $1 \mathrm{~mL}$ of $0.5 \mathrm{~N} \mathrm{NaOH}$, and $0.45 \mathrm{~mL}$ was measured for radioactivity.

\subsection{Measurement of Changes in $\left[\mathrm{Ca}^{2+}\right]_{i}$}

PC12 cells were suspended in a buffer $\left(140 \mathrm{mM} \mathrm{NaCl}, 5 \mathrm{mM} \mathrm{KCl}, 1.5 \mathrm{mM} \mathrm{CaCl}_{2}, 1 \mathrm{mM} \mathrm{MgCl}_{2}\right.$, $10 \mathrm{mM}$ HEPES, $5 \mathrm{mM}$ glucose, $\mathrm{pH} 7.4$ ) or $\mathrm{Ca}^{2+}$-free buffer $\left(140 \mathrm{mM} \mathrm{NaCl}, 5 \mathrm{mM} \mathrm{KCl}, 1 \mathrm{mM} \mathrm{MgCl}_{2}\right.$, $10 \mathrm{mM}$ HEPES, $5 \mathrm{mM}$ glucose, pH 7.4, and $0.5 \mathrm{mM}$ EGTA) and were placed in a quartz-microcuvette in a thermostat-controlled cell-holder, and then Fura-2/AM was added to a final concentration of $5 \mu \mathrm{M}$ and incubated for $30 \mathrm{~min}$ at $37^{\circ} \mathrm{C}$ under continuous stirring in the dark. Supernatants containing extracellular Fura-2/AM were removed following gentle centrifugation of $0.5 \mathrm{~mL}$ aliquots, and cells were washed three times. They were then resuspended in $1 \mathrm{~mL}$ of buffer and incubated at $37^{\circ} \mathrm{C}$ for $10 \mathrm{~min}$ prior to further centrifugation and resuspension in $4.5 \mathrm{~mL}$ of buffer at $37^{\circ} \mathrm{C}$. Then the fluorescence signal was recorded. $\left[\mathrm{Ca}^{2+}\right]_{i}$ were determined by monitoring Fura-2 fluorescence in a Shimadzu RF-5301 spectrofluorometer (Shimadzu Scientific Instruments, Columbia, MD, USA) by the dual wavelength method of Grynkiewicz et al. [48]. Under these conditions, the ratios of the fluorescence are obtained at excitation wavelengths of 340 and $380 \mathrm{~nm}$ (emission $=510 \mathrm{~nm}$ ).

\subsection{Statistical Analysis}

Data were presented as mean \pm S.E.M. and analyzed by SigmaStat software (Jandel Scientific, San Francisco, CA, USA). Pair-wise comparisons of rTCTP's effects on dopamine release compared with the relative indicated controls were analyzed using the one-tailed Student's $t$-test, considering a probability value of $p<0.05$ or 0.01 was considered statistically significant. All results are expressed as the mean \pm S.E.M.

\section{Conclusions}

We found a novel neuronal function of TCTP in stimulating dopamine release in both basal and high $\mathrm{K}^{+}$-depolarized conditions, independently of extracellular and cytosolic $\mathrm{Ca}^{2+}$, although TCTP induced an increase in $\left[\mathrm{Ca}^{2+}\right]_{\mathrm{i}}$ only under the $\mathrm{Ca}^{2+}$-containing condition. The current study strongly suggests that the rTCTP-induced neurotransmitter release from PC12 cells is mainly regulated by $\mathrm{Ca}^{2+}$-independent pathways where iPLA $A_{2}$ may be involved. Further studies are needed to verify the 
TCTP's role in the dopamine release using the in vivo experimental system or primary cultured rat neuronal cells.

Acknowledgments: This work was supported by the Basic Science Research Program through the National Research Foundation of Korea (NRF) funded by the Ministry of Education (2012-0004249) and the National Core Research Center program through the NRF funded by the Ministry of Education, Science and Technology (2011-0006244).

Author Contributions: Jihui Seo performed experiments, analyzed the data, and drafted the manuscript. Jeehye Maeng analyzed the data and was involved in the manuscript preparation. Hwa-Jung Kim designed the research, analyzed data, and wrote the manuscript. All authors read and approved the final manuscript.

Conflicts of Interest: The authors declare no conflict of interest.

\section{References}

1. Bommer, U.A.; Thiele, B.J. The translationally controlled tumour protein (TCTP). Int. J. Biochem. Cell Biol. 2004, 36, 379-385. [CrossRef]

2. Bohm, H.; Benndorf, R.; Gaestel, M.; Gross, B.; Nurnberg, P.; Kraft, R.; Otto, A.; Bielka, H. The growth-related protein P23 of the Ehrlich ascites tumor: Translational control, cloning and primary structure. Biochem. Int. 1989, 19, 277-286. [PubMed]

3. Yenofsky, R.; Bergmann, I.; Brawerman, G. Messenger RNA species partially in a repressed state in mouse sarcoma ascites cells. Proc. Natl. Acad. Sci. USA 1982, 79, 5876-5880. [CrossRef] [PubMed]

4. MacDonald, S.M.; Rafnar, T.; Langdon, J.; Lichtenstein, L.M. Molecular identification of an IgE-dependent histamine-releasing factor. Science 1995, 269, 688-690. [CrossRef] [PubMed]

5. Nagano-Ito, M.; Ichikawa, S. Biological effects of Mammalian translationally controlled tumor protein (TCTP) on cell death, proliferation, and tumorigenesis. Biochem. Res. Int. 2012, 2012. [CrossRef] [PubMed]

6. Thiele, H.; Berger, M.; Skalweit, A.; Thiele, B.J. Expression of the gene and processed pseudogenes encoding the human and rabbit translationally controlled tumour protein (TCTP). Eur. J. Biochem. 2000, 267, 5473-5481. [CrossRef] [PubMed]

7. Kim, S.H.; Cairns, N.; Fountoulakisc, M.; Lubec, G. Decreased brain histamine-releasing factor protein in patients with Down syndrome and Alzheimer's disease. Neurosci. Lett. 2001, 300, 41-44. [CrossRef]

8. Chung, C.; Tallerico, T.; Seeman, P. Schizophrenia hippocampus has elevated expression of chondrex glycoprotein gene. Synapse 2003, 50, 29-34. [CrossRef] [PubMed]

9. Andreassi, C.; Zimmermann, C.; Mitter, R.; Fusco, S.; de Vita, S.; Saiardi, A.; Riccio, A. An NGF-responsive element targets myo-inositol monophosphatase-1 mRNA to sympathetic neuron axons. Nat. Neurosci. 2010, 13, 291-301. [CrossRef] [PubMed]

10. Gumy, L.F.; Yeo, G.S.; Tung, Y.C.; Zivraj, K.H.; Willis, D.; Coppola, G.; Lam, B.Y.; Twiss, J.L.; Holt, C.E.; Fawcett, J.W. Transcriptome analysis of embryonic and adult sensory axons reveals changes in mRNA repertoire localization. RNA 2011, 17, 85-98. [CrossRef] [PubMed]

11. Roque, C.G.; Wong, H.H.; Lin, J.Q.; Holt, C.E. Tumor protein TCTP regulates axon development in the embryonic visual system. Development 2016, 143, 1134-1148. [CrossRef] [PubMed]

12. Taylor, A.M.; Berchtold, N.C.; Perreau, V.M.; Tu, C.H.; Li Jeon, N.; Cotman, C.W. Axonal mRNA in uninjured and regenerating cortical mammalian axons. J. Neurosci. 2009, 29, 4697-4707. [CrossRef] [PubMed]

13. Di Virgilio, F.; Milani, D.; Leon, A.; Meldolesi, J.; Pozzan, T. Voltage-dependent activation and inactivation of calcium channels in PC12 cells. Correlation with neurotransmitter release. J. Biol. Chem. 1987, 262, 9189-9195. [PubMed]

14. Greene, L.A.; Rein, G. Release of $\left[{ }^{3} \mathrm{H}\right]$ norepinephrine from a clonal line of pheochromocytoma cells (PC12) by nicotinic cholinergic stimulation. Brain Res. 1977, 138, 521-528. [CrossRef]

15. Kim, J.H.; Choi, S.; Jung, J.E.; Roh, E.J.; Kim, H.J. Capacitative $\mathrm{Ca}^{2+}$ entry is involved in regulating soluble amyloid precursor protein $(\mathrm{sAPP} \alpha)$ release mediated by muscarinic acetylcholine receptor activation in neuroblastoma SH-SY5Y cells. J. Neurochem. 2006, 97, 245-254. [CrossRef] [PubMed]

16. Thastrup, O.; Cullen, P.J.; Drobak, B.K.; Hanley, M.R.; Dawson, A.P. Thapsigargin, a tumor promoter, discharges intracellular $\mathrm{Ca}^{2+}$ stores by specific inhibition of the endoplasmic reticulum $\mathrm{Ca}^{2+}$-ATPase. Proc. Natl. Acad. Sci. USA 1990, 87, 2466-2470. [CrossRef] [PubMed] 
17. Abu-Raya, S.; Bloch-Shilderman, E.; Lelkes, P.I.; Trembovler, V.; Shohami, E.; Gutman, Y.; Lazarovici, P. Characterization of pardaxin-induced dopamine release from pheochromocytoma cells: Role of calcium and eicosanoids. J. Pharmacol. Exp. Ther. 1999, 288, 399-406. [PubMed]

18. Lazarovici, P.; Lelkes, P.I. Pardaxin induces exocytosis in bovine adrenal medullary chromaffin cells independent of calcium. J. Pharmacol. Exp. Ther. 1992, 263, 1317-1326. [PubMed]

19. Goetzl, E.J.; An, S.; Smith, W.L. Specificity of expression and effects of eicosanoid mediators in normal physiology and human diseases. FASEB J. 1995, 9, 1051-1058. [PubMed]

20. Hermann, P.M.; Watson, S.N.; Wildering, W.C. Phospholipase $\mathrm{A}_{2}-$ Nexus of aging, oxidative stress, neuronal excitability, and functional decline of the aging nervous system? Insights from a snail model system of neuronal aging and age-associated memory impairment. Front. Genet. 2014, 5, 419. [CrossRef] [PubMed]

21. Balsinde, J.; Balboa, M.A.; Insel, P.A.; Dennis, E.A. Regulation and inhibition of phospholipase A 2 . Annu. Rev. Pharmacol. Toxicol. 1999, 39, 175-189. [CrossRef] [PubMed]

22. Ramanadham, S.; Ali, T.; Ashley, J.W.; Bone, R.N.; Hancock, W.D.; Lei, X. Calcium-independent phospholipases $\mathrm{A}_{2}$ and their roles in biological processes and diseases. J. Lipid Res. 2015, 56, 1643-1668. [CrossRef] [PubMed]

23. Murakami, M.; Kudo, I. Phospholipase A2. J. Biochem. 2002, 131, 285-292. [CrossRef] [PubMed]

24. Singaravelu, K.; Lohr, C.; Deitmer, J.W. Regulation of store-operated calcium entry by calcium-independent phospholipase $\mathrm{A}_{2}$ in rat cerebellar astrocytes. J. Neurosci. 2006, 26, 9579-9592. [CrossRef] [PubMed]

25. Vaudry, D.; Stork, P.J.; Lazarovici, P.; Eiden, L.E. Signaling pathways for PC12 cell differentiation: Making the right connections. Science 2002, 296, 1648-1649. [CrossRef] [PubMed]

26. Yermolaieva, O.; Brot, N.; Weissbach, H.; Heinemann, S.H.; Hoshi, T. Reactive oxygen species and nitric oxide mediate plasticity of neuronal calcium signaling. Proc. Natl. Acad. Sci. USA 2000, 97, 448-453. [CrossRef] [PubMed]

27. Fasolato, C.; Pandiella, A.; Meldolesi, J.; Pozzan, T. Generation of inositol phosphates, cytosolic Ca ${ }^{2+}$, and ionic fluxes in PC12 cells treated with bradykinin. J. Biol. Chem. 1988, 263, 17350-17359. [PubMed]

28. Weiss, C.; Atlas, D. The bradykinin receptor-A putative receptor-operated channel in PC12 cells: Studies of neurotransmitter release and inositol phosphate accumulation. Brain Res. 1991, 543, 102-110. [CrossRef]

29. Adam-Vizi, V.; Ligeti, E. Release of acetylcholine from rat brain synaptosomes by various agents in the absence of external calcium ions. J. Physiol. 1984, 353, 505-521. [CrossRef] [PubMed]

30. Schwartz, E.A. Depolarization without calcium can release $\gamma$-aminobutyric acid from a retinal neuron. Science 1987, 238, 350-355. [CrossRef] [PubMed]

31. Nicholls, D.G.; Sihra, T.S.; Sanchez-Prieto, J. Calcium-dependent and -independent release of glutamate from synaptosomes monitored by continuous fluorometry. J. Neurochem. 1987, 49, 50-57. [CrossRef] [PubMed]

32. Lonart, G.; Zigmond, M.J. High glutamate concentrations evoke $\mathrm{Ca}(++)$-independent dopamine release from striatal slices: A possible role of reverse dopamine transport. J. Pharmacol. Exp. Ther. 1991, 256, 1132-1138. [PubMed]

33. Hochner, B.; Parnas, H.; Parnas, I. Membrane depolarization evokes neurotransmitter release in the absence of calcium entry. Nature 1989, 342, 433-435. [CrossRef] [PubMed]

34. Bloch-Shilderman, E.; Abu-Raya, S.; Trembovler, V.; Boschwitz, H.; Gruzman, A.; Linial, M.; Lazarovici, P. Pardaxin stimulation of phospholipases $\mathrm{A}_{2}$ and their involvement in exocytosis in PC-12 cells. J. Pharmacol. Exp. Ther. 2002, 301, 953-962. [CrossRef] [PubMed]

35. Bonventre, J.V. Roles of phospholipases $\mathrm{A}_{2}$ in brain cell and tissue injury associated with ischemia and excitotoxicity. J. Lipid Mediat. Cell Signal. 1997, 16, 199-208. [CrossRef]

36. Matsuzawa, A.; Murakami, M.; Atsumi, G.; Imai, K.; Prados, P.; Inoue, K.; Kudo, I. Release of secretory phospholipase $\mathrm{A}_{2}$ from rat neuronal cells and its possible function in the regulation of catecholamine secretion. Biochem. J. 1996, 318, 701-709. [CrossRef] [PubMed]

37. Ray, P.; Berman, J.D.; Middleton, W.; Brendle, J. Botulinum toxin inhibits arachidonic acid release associated with acetylcholine release from PC12 cells. J. Biol. Chem. 1993, 268, 11057-11064. [PubMed]

38. Song, H.S.; Ko, M.S.; Jo, Y.S.; Whang, W.K.; Sim, S.S. Inhibitory effect of acteoside on melittin-induced catecholamine exocytosis through inhibition of $\mathrm{Ca}^{2+}$-dependent phospholipase $\mathrm{A}_{2}$ and extracellular $\mathrm{Ca}^{2+}$ influx in PC12 cells. Arch. Pharm. Res. 2015, 38, 1913-1920. [CrossRef] [PubMed] 
39. Yang, C.W.; Rathinavelu, A.; Borowitz, J.L.; Isom, G.E. Activation of a calcium- and pH-dependent phospholipase $\mathrm{A}_{2}$ by cyanide in PC12 cells. Toxicol. Appl. Pharmacol. 1994, 124, 262-267. [CrossRef] [PubMed]

40. Dennis, E.A.; Cao, J.; Hsu, Y.H.; Magrioti, V.; Kokotos, G. Phospholipase $\mathrm{A}_{2}$ enzymes: Physical structure, biological function, disease implication, chemical inhibition, and therapeutic intervention. Chem. Rev. 2011, 111, 6130-6185. [CrossRef] [PubMed]

41. Farooqui, A.A.; Ong, W.Y.; Horrocks, L.A. Inhibitors of brain phospholipase $\mathrm{A}_{2}$ activity: Their neuropharmacological effects and therapeutic importance for the treatment of neurologic disorders. Pharmacol. Rev. 2006, 58, 591-620. [CrossRef] [PubMed]

42. Yang, H.C.; Mosior, M.; Ni, B.; Dennis, E.A. Regional distribution, ontogeny, purification, and characterization of the $\mathrm{Ca}^{2+}$-independent phospholipase $\mathrm{A}_{2}$ from rat brain. J. Neurochem. 1999, 73, 1278-1287. [CrossRef] [PubMed]

43. Smani, T.; Dominguez-Rodriguez, A.; Callejo-Garcia, P.; Rosado, J.A.; Avila-Medina, J. Phospholipase $\mathrm{A}_{2}$ as a Molecular Determinant of Store-Operated Calcium Entry. Adv. Exp. Med. Biol. 2016, 898, 111-131. [PubMed]

44. Vonakis, B.M.; Macglashan, D.W., Jr.; Vilarino, N.; Langdon, J.M.; Scott, R.S.; MacDonald, S.M. Distinct characteristics of signal transduction events by histamine-releasing factor/translationally controlled tumor protein (HRF/TCTP)-induced priming and activation of human basophils. Blood 2008, 111, 1789-1796. [CrossRef] [PubMed]

45. Schroeder, J.T.; Lichtenstein, L.M.; MacDonald, S.M. An immunoglobulin E-dependent recombinant histamine-releasing factor induces interleukin-4 secretion from human basophils. J. Exp. Med. 1996, 183, 1265-1270. [CrossRef] [PubMed]

46. MacGlashan, D., Jr.; Botana, L.M. Biphasic $\mathrm{Ca}^{2+}$ responses in human basophils. Evidence that the initial transient elevation associated with the mobilization of intracellular calcium is an insufficient signal for degranulation. J. Immunol. 1993, 150, 980-991. [PubMed]

47. Balboa, M.A.; Balsinde, J.; Dennis, E.A. Involvement of phosphatidate phosphohydrolase in arachidonic acid mobilization in human amnionic WISH cells. J. Biol. Chem. 1998, 273, 7684-7690. [CrossRef] [PubMed]

48. Grynkiewicz, G.; Poenie, M.; Tsien, R.Y. A new generation of $\mathrm{Ca}^{2+}$ indicators with greatly improved fluorescence properties. J. Biol. Chem. 1985, 260, 3440-3450. [PubMed]

(C) 2016 by the authors; licensee MDPI, Basel, Switzerland. This article is an open access article distributed under the terms and conditions of the Creative Commons Attribution (CC-BY) license (http://creativecommons.org/licenses/by/4.0/). 